\title{
MOTIVATION OF FRESH GRADUATE STUDENTS WHO LEAVE A FAMILY BUSINESS
}

\author{
Evaldo Hans S.R., Mirza Dwinanda Ilmawan, Aditya Narendra Wardhana \\ Fakultas Ekonomi dan Bisnis \\ Universitas Internasional Semen Indonesia
}

\begin{abstract}
The purpose of this study is to examine some of the main reasons for successor from family businesses who do not want to continue their family business. This study uses qualitative methods using the approach of in-depth interviews with respondents. The research respondents were fresh graduates who did not want to continue the family business that had been initiated by a large family of respondents. The findings in this study prove that respondents prefer to avoid conflicts with relatives or the absence of succession in family business. Career opportunities from other companies are another factor in making decisions to leave the family business.
\end{abstract}

Keywords: Family Business, Fresh Graduate, Family Conflict, Succession

\section{PENDAHULUAN}

95 persen perusahaan di Indonesia dimiliki oleh perusahaan keluarga (Siregar, 2016). Definisi bisnis keluarga menurut Zubir (2008) bisnis yang dimiliki dan dikelola bersama oleh orang-orang yang memiliki hubungan keluarga. Orang tua yang memiliki bisnis keluarga, pada dasarnya memiliki keinginan untuk terus eksis pada dunia bisnis. Keinginan ini dapat dilakukan salah satunya dengan perencanaan suksesi (Paradhita dan Mukzam, 2017).

Definisi perencanaan suksesi menurut Sudiro (2011) adalah proses antisipasi kebutuhan managerial staffing di masa yang akan datang serta pembuatan perencanaan untuk pengembangannya. Tanpa disadari bisnis keluarga yang telah dirintis oleh orang tua, sangat mempengaruhi pilihan karir generasi selanjutnya di masa depan. Bagi generasi yang ingin melanjutkan bisnis keluarga atas dasar keinginan sendiri dapat disebabkan karena factor motivasi internal, yaitu mereka menemukan peluang yang baik yang dalam bisnis keluarga, dimana mereka menemukan keseimbangan antara keluarga dan bisnis, serta memiliki hubungan dengan tanggung jawab dan minat karir atau pribadinya (Wijaya, 2016). Menurut Hasibuan pentingnya pemberian motivasi karena merupakan hal yang dapat menyebabkan, menyalurkan dan mendukung perilaku agar mau bekerja giat dan antusias untuk mencapai hasil yang optimal. Tetapi tidak semua anak atau generasi penerus ingin melanjutkan atau mengembangkan bisnis keluarganya. Hal ini bisa saja disebabkan oleh faktor motivasi eksternal yang ada seperti jabatan yang ditawarkan oleh perusahaan besar, kompensasi yang tinggi dan jenjang karir yang menjanjikan di luar lingkungan bisnis keluarga.

Seperti yang dikutip pada liputan6.com (2016), survey yang dilakukan oleh Universitas Jiaotong Shanghai menyatakan bahwa lebih dari $80 \%$ ahli waris di China tidak 
tertarik untuk mengambil kendali bisnis keluarganya. Selain itu, studi oleh swasta China juga menyatakan bahwa beberapa ahli waris memilih menolak untuk mengambil peran bisnis keluarga karena adanya tekanan dan sebagian ada yang tengah mengejar mimpinya.

Objek pada penelitian ini adalah salah satu mahasiswa fresh graduate UISI yakni Fatimatus Zahra yang memutuskan untuk meninggalkan bisnis keluarga dan saat ini telah bekerja di PT Surganya Motor Indonesia bagian HR Personalia. Orang tua dari objek ini memiliki beberapa bisnis seperti depot air mineral, elpiji, tiket pesawat dan warung makan yang berada di Kota Gresik dan Bawean.

Peneliti ingin menggali lebih dalam alasan terkait objek yang meninggalkan bisnis keluarga dan lebih memilih berkarir di luar bisnis keluarga. Berdasarkan latar belakang diatas, maka peneliti menggunakan pendekatan kualitatif dengan teknik wawancara untuk mengetahui motivasi apa saja yang menyebabkan objek meninggalkan bisnis keluarga.

\section{TINJAUAN PUSTAKA}

Defnisi bisnis keluarga menurut Leach (2007) adalah bisnis yang dipengaruhi keluarga ataupun hubungan antar anggota keluarga, seperti ayah dan anak, antar saudara, saudara sepupu, yang mana hubungan ini memiliki dampak yang besar pada masa depan perusahaan. Zubir (2008) juga mengemukakan bahwa bisnis keluarga adalah bisnis yang dimiliki dan dikelola bersama oleh orang-orang yang memiliki hubungan keluarga. Biasanya, hubungan keluarga tersebut melingkupi pasangan hidup, anak, orang tua, saudara sekandung dansaudara jauh. Pandangan dari
Soedibyo (2012) bahwa, "Ciri utama perusahaan keluarga ialah kepemilikan dan keterlibatan yang signifikan dari keluarga dalam manajemen perusahaan". Lebih lanjut Soedibyo (2012) menjelaskan ciri atau karakteristik utama perusahaan keluarga yaitu terdapat satu atau lebih anggota keluarga yang berada pada pimpinan puncak dan adanya kontrol yang besar dari keluarga ke perusahaan.

Definisi motivasi menurut Martoyo (2000) adalah suatu dorongan yang menjadi pangkal seseorang melakukan sesuatu. Selain itu, motivasi dapat juga dikatakan bahwa faktor yang mendorong orang untuk bertindak dengan cara tertentu.

Pemberian motivasi ini sangat penting untuk diberikan kepada suksesor bisnis keluarga agar lebih antusias dan giat untuk mengejar suatu tindakan tertentu. Menurut Hasibuan (2013) pentingnya motivasi karena motivasi adalah hal yang menyebabkan, menyalurkan dan mendukung perilaku manusia, supaya mau bekerja giat dan antusias mencapai hasil yang optimal. Motivasi mengacu pada kekuatan, baik dari dalam (internal) maupun luar (eksternal) yang membangkitkan antusiasme dan ketekunan, guna mengejar suatu tindakan tertentu.

Perencanaan suksesi merupakan bagian dari perencanaan sumber daya manusia, yang dalam pelaksanaannya harus disesuaikan dengan strategi perusahaan agar tujuan utama perencanaan tercapai (Paradhita dan Mukzam, 2017). Pengertian perencanaan suksesi menurut Sudiro (2011) adalah proses antisipasi kebutuhan managerial staffing dimasa yang akan datang serta pembuatan perencanaan untuk pengembangannya. 


\section{METODOLOGI PENELITIAN}

Metode penelitian yang digunakan dalam penelitian ini adalah metode kualitatif deskriptif dengan pendekatan studi kasus. Menurut Sugiyono (2012) metode kualitatif untuk meneliti kondisi objek yang alamiah di mana peneliti berperan sebagai instrumen kunci, teknik pengumpulan data dilakukan secara gabungan, analisis data bersifat induktif dan hasil penelitian kualitatif lebih menekankan pada makna.

Penelitian ini dilaksanakan di Kabupaten Gresik tepatnya di bisnis keluarga milik orang tua dari Fatimatus Zahra. Teknik pengumpulan data ini dapat dilakukan dengan berbagai cara yaitu observasi, wawancara dan dokumentasi.

Dalam penelitian kualitatif, data diperoleh dari berbagai sumber dengan menggunakan teknik pengumpulan data yang bermacam-macam dan dilakukan secara terus menerus sampai datanya jenuh (Sugiyono, 2012). Dengan pengamatan yang terus menerus tersebut mengakibatkan variasi data yang tinggi.

Analisis data dalam penelitian kualitatif, dilakukan pada saat tua Syahri yaitu toko sembako, memiliki sentral hasil sumber daya laut berupa ikan pindang yang dikirim ke Kalimantan dan juga usaha jual beli tanah. Pada tanggal 15 Maret 1988 beliau akhirnya menikah dengan Masnawiyah dari pasangan Sa'id dengan Hoiriyah. Untuk mencukupi kebutuhan rumah tangganya Syahri diberi warisan oleh orang tuanya sebuah toko yang ada di pasar. Setelah 4 tahun, mereka dikaruniai anak yang pertama lahir pada tanggal 7 Maret 1992 bernama Nur Janna. Pada saat anak pertama lahir, usaha toko sembako di pasar yang dijalankan dirasa semakin ramai pembeli. Semua merupakan metode baru karena popularitasnya dinyatakan belum lama. Metode kualitatif merupakan metode penelitian yang berlandaskan pada filsafat postposotivisme, digunakan

pengumpulan data berlangsung dan setelah selesai pengumpulan data dalam periode tertentu. Menurut Sugiyono (2012) terdapat 3 macam aktivitas dalam analisis data yaitu, reduksi data (data reduction), penyajian data (data display) dan conclusion drawing/verification. Dalam penelitian ini pengecekan keabsahan data dilakukan dengan cara triangulasi. Peneliti menggunakan triangulasi sumber dan triangulasi pengumpulan data.

\section{SEJARAH BISNIS KELUARGA}

Syahri merupakan masyarakat asli Bawean yang lahir pada tanggal 29 Juni 1969 dari pasangan Masduki Dengan Sum'ah. Beliau merupakan anak ke 2 dari 3 bersaudara. Semasa mudanya, Syahri ini sering membantu usaha dari orang tuanya yang berada di Bawean hingga menikah. Usaha yang dimiliki oleh orang

yang dirasakan oleh Syahri ketika awal menjalankan usaha toko sembakonya hingga pada tanggal 8 Juni 1995 Syahri dikaruniai anak yang kedua bernama Fatimatus Zahra. Setelah hadirnya anak kedua ini, Syahri mampu membuka toko sembako lagi dengan modal awal dari pundi-pundi keuntungan yang telah dikumpulkan oleh Syahri dari usaha toko sembakonya di mana toko yang pertama ini beralih menjadi gudang untuk penyimpanan barang dagangan berupa sembako. Toko yang kedua yaitu toko sembako yang letaknya di pasar ini dikelola oleh istrinya dan Syahri mengelola di gudang miliknya 
saja. Hal yang dilakukan Syahri dengan mengumpulkan pundi-pundi keuntungan untuk penambahan modal usaha berikutnya sejalan dengan salah satu karakter bisnis keluarga yang dijelaskan Marpa (2012) yaitu manajemen keuangan dalam bisnis keluarga bersifat konservatif. Konservatif di sini maksudnya adalah berhutang pada bisnis yang terdahulu untuk mengembangkan bisnis selanjutnya dan senantiasa berhati-hati dalam memilih lokasi dan biaya untuk perlengkapan dagang. Setelah berjalan selama 1 tahun toko sembako ini akhirnya bisa ramai pembeli lagi. Pada akhirnya Syahri mampu merenovasi tokonya menjadi lebih besar lagi dari pundi-pundi keuntungan toko tersebut. Setelah masa pernikahan pasangan Syahri dengan Masnawiyah ini menginjak 11 tahun, mereka dikaruniai seorang anak laki-laki yang lahir pada tanggal 12 Agustus 1999 bernama Abdul Muqsit. Setelah beberapa bulan hadirnya anak yang ketiga, Syahri tergoda untuk membuka usaha baru yang dirasa masuk akal yaitu, sebagai pengawal Tenaga Kerja Indonesia dan juga Syahri menyadari bahwa sebagian besar penduduk Bawean banyak yang menjadi Tenaga Kerja Indonesia.

Setelah tergoda dengan bisnis tersebut akhirnya syahri mempelajari bagaimana sistem untuk menjadi pengawal mulai dari administrasi, memesan tiket dan mengurus passport. Setelah mempelajari selama 1 bulan, akhirnya Syahri memutuskan untuk merantau ke Gresik karena teman yang mengenalkan bisnis pengawal Tenaga Kerja Indonesia ini berada di Gresik. Di Gresik juga terdapat sebuah penginapan khusus untuk orang Bawean di mana bisa menjadi potensi untuk bisnis ini. Ketika merantau, usaha toko yang berada di Bawean diserahkan kepada keponakan Syahri untuk dilanjutkan karena keponakan ini yang merawat ibunya Syahri. Setelah menjalankan usaha sebagai pengawal selama 3 tahun, Syahri dikaruniai anak yang keempat bernama Latifah dan lahir pada tanggal 15 Agustus 2002. Dengan hadirnya anak keempat ini Syahri merasakan bahwa rezekinya juga bertambah, hal ini dibuktikan dengan semakin banyaknya orang yang ingin menjadi Tenaga Kerja Indonesia melalui jasa beliau untuk dikawal dan dibantu prosesnya. Selain itu konsumennya juga berkembang, yang awalnya orang Bawean saja kini berkembang dari berbagai daerah. Setahun kemudian dari kelahiran anak keempatnya, Syahri dikaruniai anak kelima yang lahir pada 14 November 2003 bernama Dewi Fitriana. Dengan hadirnya anak kelima ini beliau mendapatkan rezeki yang tidak terduga yaitu mendapatkan tempat tinggal yang tetap di mana sebelumnya pada saat awal merantau tinggal di sebuah kontrakan.

Seiring berjalannya waktu, beliau terpikirkan untuk membuka bisnis tiket pesawat berbasis online. Transportasi yang digunakan untuk mengantar Tenaga Kerja Indonesia adalah pesawat dan beliau beranggapan bahwa bisnis ini mempunyai peluang yang besar karena banyak masyarakat Bawean yang belum melirik peluang bisnis ini dengan memanfaatkan teknologi. Jadi beliau berpikir, "ketika saya menjadi pengawal, sekalian saja saya menjual tiket pesawat untuk Tenaga Kerja Indonesia dan dirasa bisa mendapakan keuntungan yang berlipat". Sehingga pada Tahun 2007 beliau akhirnya mendirikan bisnis tiket online tersebut. Bisnis tiket online ini memiliki badan usaha yang berbentuk $\mathrm{CV}$ dan 
bernama CV Sahara Jaya Lestari. Beliau memulai bisnis tiket online ini di rumahnya yang berada di Kota Gresik ini dengan modal awal yang digunakan menggunakan kartu kredit, kemudian laptop dan mobil pribadi untuk jasa antar jemput dari bandara ke Gresik atau tujuan lainnya. Modal ini didapat Syari dari pundi-pundi pada saat menjadi pengawal untuk mengurus keperluan masyarakat Bawean yang menjadi Tenaga Kerja Indonesia. Seiring berjalannya waktu, bisnis ini melayani penerbangan secara umum juga dan beruntungnya Syahri yang telah memutuskan untuk membuka di Kota Gresik di mana perkembangan ekonominya terbilang lebih baik karena Gresik adalah sebagai kota industri di mana banyak kaum perantau yang berasal dari luar pulau dan ini bisa mengembangkan pangsa pasar dari usaha ini. Selain tiket online, bisnis ini juga melayani jasa antar jemput dari bandara ke Gresik atau tujuan lain (travel).

Tantangan saat itu adalah semakin banyaknya kompetitor penyedia jasa tiket online dan transportasi berbasis online. Selain itu, usaha yang dilakukan beliau ini hanya memiliki 1 orang pegawai dan hanya mampu bertahan selama beberapa bulan saja karena berat di beban biaya. Beliau juga mempunyai anggapan selama itu masih bisa dilakukan sendiri ya dilakukan sendiri. Namun perkembangan usaha tiket online saat ini (2018) tidak seramai pada saat masa puncak kejayaannya yaitu pada Tahun 2010 di mana bersamaan juga dengan kelahiran anak Syahri yang terakhir yang lahir pada 21 April 2010 yang bernama Syahrini Apriliya. Beliau juga merasakan pada Tahun 2011, pendapatan dari tiket online ini semakin menurun karena semakin banyaknya kompetitor bisnis yang bergerak di bidang yang sama dan beliau hanya mengandalkan penjualan tiket online saja sedangkan di Pulau Jawa, tiket online sering digandengkan dengan paket tour dan travel.

Pada tahun 2011 beliau akhirnya memutuskan untuk mendirikan bisnis depo air isi ulang yang didirikan di Bawean. Beliau memutuskan untuk mendirikan bisnis depo air isi ulang karena beliau melihat peluang bahwa di Bawean terdapat sumber mata air bersih yang dapat diminum. Selain itu, masih belum banyak orang Bawean yang melihat peluang jika sumber mata air di Bawean dapat diminum dan beliau juga ingin mengubah kebiasaan masyarakat Bawean yang sering mengkonsumsi air sumur menjadi mengkonsumsi air isi ulang yang berasal dari sumber di salah satu gunung di Bawean.

Sembari menjalankan bisnis depo air isi ulang, beliau bekerja sama dengan salah satu agen elpiji yang berada di Kota Gresik untuk memasok elpiji ke Bawean. Beliau melihat peluang di bisnis elpiji ini karena banyak Masyarakat Bawean yang membeli dari toko yang lebih besar untuk dijual kembali sehingga beliau memutuskan ingin menjadi salah satu pemasok yang ada di Bawean. Untuk bisnis elpiji ini beliau mendatangkan elpiji dari Kota Gresik dengan bantuan perahu milik teman beliau.

Setelah dirasa bisnis depo air isi ulang dan agen elpiji berkembang, beliau akhirnya memutuskan untuk mendirikan bisnis lagi di samping bisnis sebelumnya yaitu konter Hp. Bisnis ini hanya menjual pulsa dan kartu perdana yang diambil dari Kota Gresik. Beliau mendirikan bisnis ini di depan rumah dengan bermodalkan etalase kecil. Beliau memutuskan untuk mendirikan bisnis konter HP ini karena melihat bahwa di Bawean 
sudah banyak didirikan menara sutet di mana dapat memperkuat sinyal yang digunakan untuk telepon, mengirimkan pesan singkat dan mengakses internet. Kendala dalam menjalankan bisnis adalah mahalnya ongkos kirim transport karena barang yang dikirim berasal dari Kota Gresik. Bisnis ini berdiri pada Tahun 2014 dan modal yang digunakan berasal dari pundi-pundi keuntungan dari bisnis sebelumnya.

Untuk menambah pundi-pundi demi mencukupi kebutuhan rumah tangganya, pada awal tahun 2017 Syahri mendirikan bisnis warung makan beserta warung kopi yang berada di dekat pelabuhan Gresik dan saat ini dikelolah oleh istrinya yaitu Masnawiyah. Beliau mendirikan bisnis ini karena melihat peluang di sekitar warung makan tersebut dekat dengan Pelabuhan Gresik dimana orang yang setelah menyebrang dari Bawean juga mampir untuk sekedar ngopi dan mengisi perut dan juga dekat dengan Polres Gresik dimana para anggota dan staf dari kepolisian tersebut makan dan menghabiskan waktu istirahatnya di daerah tersebut. istri beliau juga memiliki harapan usaha warung makan ini bisa berkembang menjadi usaha catering.

Untuk saat ini beliau hanya fokus pada usaha atau bisnis yang berada di Bawean karena modal yang digunakan cukup besar melebihi modal awal ketika mendirikan usaha tiket pesawat online. Untuk usaha yang didirikan di Bawean ini menurut beliau terbilang jarang ada kompetitor dan dapat dikatakan hanya beliau saja yang mendirikan. Untuk usaha atau bisnis mulai dari tiket online, depo air isi ulang, agen elpiji, hingga konter Hp semua dilakukan oleh Syahri murni didirikan mulai dari nol dalam artian bukan merupakan usaha turunan dari orang tua beliau meskipun sebelumnya orang tua dari Syahri telah memiliki bisnis keluarga.

\section{SUKSESI DALAM BISNIS KELUARGA}

Dalam menjalankan sebuah roda kegiatan bisnis keluarga, sangat penting untuk melakukan proses perencanaan suksesi. Proses suksesi ini merupakan tahapan yang sangat penting dan menentukan keberlanjutan dari sebuah bisnis keluarga (Dhewanto, 2012). Menurut Sudiro (2011) proses perencanaan suksesi adalah proses di mana mengantisipasi kebutuhan managerial staffing di masa yang akan datang serta pembuatan perencanaan untuk pengembangannya. Bisnis keluarga yang telah dirintis oleh Syahri ini tidak melakukan proses suksesi dalam artian tidak akan diturunkan kepada siapapun. Hal ini bertolak belakang dengan apa yang diungkapkan oleh Dhewanto (2012) bahwa rencana suksesi dalam bisnis keluarga merupakan hal yang sulit diabaikan. Suksesi merupakan momen penting dalam keberadaan bisnis keluarga karena untuk menjaga keeksisan bisnis keluarga tersebut. Bisnis keluarga milik keluarga besar Syahri ini tidak pernah menurunkan tongkat estafet bisnisnya kepada generasi penerus. Faktor suksesi ini tidak diperhatikan oleh keluarga besar Syahri sehingga tidak ada satu pun yang berkeinginan untuk melanjutkan bisnis keluarga tersebut. Hal ini menurun hingga ke anak-anak Syahri di mana tidak ada satu pun yang berkeinginan untuk melanjutkan bisnisnya. Bisnis yang dilakukan ini hanya sekedar untuk memenuhi kebutuhan sehari-hari saja dan belum memikirkan untuk mengembangkan bisnisnya. 
Dengan adanya hal tersebut, proses suksesi tidak berjalan dengan baik. Keluarga besar Syahri secara keseluruhan dalam bisnis keluarganya tidak melibatkan anak-anaknya untuk suksesi usaha. Syahri justru membiarkan anak-anaknya untuk memilih berkarir di luar bisnis keluarga. Meskipun salah satu anak Syahri yaitu Fatimah yang memiliki pengetahuan tentang entrepreneur, Syahri justru tidak memanfaatkan hal tersebut untuk menumbuhkan jiwa kewirausahaanya. Syahri juga tidak membiasakan anak-anaknya untuk terjun langsung dalam bisnisnya.

Untuk mengembangkan bisnis harus memiliki tujuan. Tujuan ini dapat digambarakan melalui visi dan misi yang jelas. Bisnis keluarga yang telah dirintis oleh Syahri ini tidak memiliki visi dan misi. Hal ini sangat disayangkan karena visi dan misi merupakan pondasi penting dalam suatu bisnis. Menurut Kunde (2000) pentingnya visi dan misi dalam suatu usaha adalah sebagai pedoman dalam merencanakan strategi dalam jangka waktu yang panjang.

Selain tidak memiliki visi dan misi yang jelas, bisnis keluarga yang telah dirintis oleh Syahri ini juga tidak memiliki struktur organisasi. Hal ini bertolak belakang dengan apa yang diungkapkan Dhewanto (2012) bahwa dalam membangun bisnis keluarga salah satu hal yang penting memiliki struktur organisasi dan tata kelola yang jelas. Keberadaan struktur organisasi akan sangat membantu pembagian tugas dan insentif dari pekerjaan yang telah dilakukan.

Untuk perihal suksesi, beliau sempat menawarkan kepada anak yang pertama (Nur Janah) dan yang ketiga (Abdul Muqsit) untuk melanjutkan, namun mereka menolak karena memilih untuk berkarir sendiri.
Dengan adanya respon seperti itu, Syahri akhirnya membiarkan anakanaknya untuk menetukan karir yang diinginkan. Hal ini dapat ditunjukkan dari hasil wawancara dengan Syahri yaitu,

"tidak menunjuk siapa-siapa untuk melanjutkan, karena saya tidak memaksa anak-anak untuk melanjutkan, biar mereka sendiri yang mementukan mau berkarir sebagai apa”.

Selain tidak menunjuk anakanaknya untuk melanjutkan, Syahri juga tidak menunjuk orang lain (tenaga profesional) untuk melanjutkan bisnisnya. "Beliau merupakan tipikal orang yang sulit percaya terhadap orang yang baru dikenal", menurut putri kedua beliau (Fatimah). Selain itu, beliau memutuskan untuk menjalankan bisnisnya ini semampunya. Beliau menyatakan bahwa,

“tidak, saya akan menjalankan usaha ini sampai semampu saya, karena saya juga tidak gampang percaya dengan orang yang belum saya kenal maka dari itu usaha saya tidak akan dilanjutkan oleh orang lain meskipun anak-anak saya tidak ada yang ingin melanjutkan".

Pernyataan Syahri ini sesuai dengan apa yang diungkapkan oleh Suharno (2009) bahwa pemilik bisnis seringkali sebagai pelaksana bukan sebagai business owner". Dapat dikatakan sebagai business owner apabila dapat meninggalkan bisnis tanpa mengganggu kinerja bisnis tersebut. Suharno (2009) juga mengungkapkan bahwa bisnis yang normal sebaiknya yang ditinggal oleh pemiliknya. Namun demikian Syahri tidak akan diturunkan kepada siapapun baik dari pihak keluarga maupun orang lain. Hal ini sangat 
disayangkan karena usaha atau bisnis yang telah dirintis oleh Bapak Syahri ini memiliki potensi yang menjanjikan karena masih sedikit usaha yang bergerak di Pulau Bawean terutama depo air isi ulang.

Syahri mulai mengenalkan usahanya kepada anak kedua yaitu Fatimah pada saat berada di bangku SMA (Sekolah Menengah Atas). Sedikit demi sedikit Fatimah mulai memahami seluk beluk tiket berbasis online. Namun beliau tidak pernah melibatkan Fatimah secara penuh dalam kegiatan bisnis tersebut. Hanya saja Fatimah terkadang diberikan tugas memesankan tiket untuk konsumen ketika Bapak Syahri sedang berada di luar kota atau ada kepentingan lain. Syahri juga tidak pernah menanamkan pedomanpedoman atau pendidikan tentang berwirausaha kepada anak-anaknya. Beliau juga membebaskan anakanaknya untuk memilih sekolah.

Untuk melibatkan anggota keluarganya, Syahri mengagendakan untuk family meeting. Family meeting ini maksudnya adalah mengadakan pertemuan keluarga untuk berkomunikasi dan berdiskusi untuk membahas mengenai pengambilan keputusan, pemecahan masalah, dorongan dan kerjasama antar anggota keluarga (Dhewanto, 2012). Dengan adanya agenda family meeting setiap anggota kekuarga dapat terlibat dan memberikan kontribusi dalam bisnis keluarga tersebut.

\section{SEKOLAH HANYA UNTUK MENUNTUT ILMU}

Orang Tua Fatimah menyekolahkan Fatimah ke salah satu perguruan tinggi swasta yang berbasis korporasi yaitu UISI (Universitas Internasional Semen Indonesia), tidak untuk memberikan bekal ilmu dan pengetahuan demi melanjutkan usahanya nanti, tetapi hanya untuk menjadi Sarjana Ekonomi saja. Hal ini dapat dibuktikan dari hasil wawancara dengan Syahri yaitu,"Tidak, saya menyekolahkan Fatimah di UISI hanya ingin agar dia menjadi sarjana ekonomi saja."

Padahal dengan menyekolahkan Fatimah di UISI ini sebenarnya memiliki potensi untuk belajar menjadi wirausaha. Salah satu program studi yaitu manajemen yang ada di UISI ini memiliki visi tentang entreprenurship. Selain mempunyai visi entrepreneurship, di departemen Manajemen UISI juga terdapat mata kuliah yang melatih mahasiswa untuk membangun bisnis start up. Mata kuliah tersebut adalah KWU (Kewirausahaan) dan PPB (Proyek Penciptaan Bisnis). Selain melatih mahasiswa untuk memulai bisnis, ada salah satu mata kuliah yang ditujukan untuk melatih mahasiswa dalam berbisnis sosial di mana keuntungan dari bisnis tersebut digunakan untuk kegiatan sosial yaitu PBS (Proyek Bisnis Sosial).

Pada masa studi di UISI, nilai dari mata kuliah yang berkaitan dengan berbisnis seperti KWU (kewirausahaan), PPB (Proyek Penciptaan Bisnis) dan PBS (Proyek Bisnis Sosial). Fatimah mendapatkan nilai yang sangat baik dan dirasa penulis berpotensi untuk melanjutkan bisnis keluarganya dan mempunyai bakat dalam berwirausaha. Tetapi, dengan mendapatkan nilai akademis yang berkaitan dengan berwirausaha, Fatimah tetap tidak berminat untuk melanjukan bisnis keluarga yang telah dirintis oleh orang tuanya. Berwirausaha bukan merupakan keinginan dari Fatimah dan memilih untuk bekerja di sebuah perusahaan. Hal ini dapat dibuktikan dengan hasil wawancara dengan Fatimah yaitu, 
"Jika disuruh memilih antara bekerja atau berwirausaha saya lebih prefer bekerja dengan orang lain karena pada saat bekerja dengan orang lain diperlakukan sama dan tidak ada keterikatan yang lebih penting. Ketika bekerja dengan tidak adanya keterikatan orang tua, bisa lebih profesional dan pada saat terjadi suatu masalah bisa diselesaikan dengan bantuan perusahaan sesuai prosedurnya. Tetapi, pada saat kita bekerja dengan keluarga dan terjadi permasalahan itu bisa mempengaruhi hubungan saya dengan keluarga saya dan saya tidak menginginkan hal itu terjadi".

Hal ini juga sesuai dengan pernyataan dari Nur Janah yang merupakan kakak dari Fatimah. Menurutnya. "Fatimah tidak berminat untuk terjun ke dunia usaha dan memilih untuk bekerja di perusahaan."

Fatimah juga memutuskan untuk meninggalkan bisnis keluarga dan memutuskan untuk berkarir di luar bisnis keluarga. Pengambilan keputusan karir yang diambil oleh Fatimah tentunya dipengaruhi beberapa faktor. Sebelumnya pengambilan keputusan karir ini mempunyai pengertian yaitu proses yang ditetapkan oleh seseorang berdasarkan motivasi, pengetahuan, kepribadian dan kemampuan seseorang (Nurhidayati, 2018). Pengambilan keputusan karir ini dipengaruhi oleh beberapa faktor antara lain, minat, sikap, kepribadian dan pengetahuan yang dikutip dari Nurhidayati (2018). Jika dikaitkan dengan Fatimah, Fatimah tidak berminat dengan dunia wirausaha karena bukan merupakan tipe karir yang dinginkan olehnya. Selain itu,
Fatimah menunjukan sikap acuh terhadap bisnis keluarga yang telah dirintis oleh orang tuanya karena tidak ada ketertarikan dengan dunia entrepreneur. Untuk faktor kepribadian, Fatimah memiliki kepribadian yang tidak suka mengambil risiko di mana menurut Fatimah berkarir sebagai entrepreneur sangat berisiko. Selain itu, Fatimah juga mempunyai pandangan bahwa yang cocok untuk melakukan bisnis adalah kaum lelaki. Hal ini dapat dibuktikan dari hasil wawancara dengan Fatimah yaitu,

"Tidak, alasan yang pertama, itu bukan merupakan tipe saya, karena saya tipe orang yang tidak suka mengambil risiko. Kemudian saya ingin berkarir sendiri tetapi tidak berwirausaha melainkan kerja di perusahaan dan juga saya sebagai perempuan mempunyai pandangan bahwa bisnis yang cocok itu dikelola oleh laki-laki".

Pernyataan dari Fatimah yang memutuskan untuk meninggalkan bisnis keluarga ini juga dibenarkan oleh Nur Janah. Nur Janah menyatakan bahwa,

"Fatimah tidak berminat untuk melanjutkan bisnis ayah saya, Fatimah juga pernah mengatakan kepada saya bahwa lebih tertarik untuk berkarir sendiri dengan memilih bekerja di perusahaan".

Fatimah juga beranggapan bahwa, apabila berkarir dengan keluarga dalam artian melanjutkan usaha dari keluarga dan terjadi suatu permasalahan, itu bisa mempengaruhi hubungan Fatimah dengan keluarganya dan dia tidak menginginkan hal itu terjadi. Selain itu, menurut Fatimah kalau bisnis ya bisnis, keluarga ya keluarga.

Dengan adanya sikap Fatimah yang menghindari konflik dengan 
keluarga tersebut. Maka pencetus bisnis keluarga dapat melakukan manajemen konflik. Manajemen konflik adalah suatu tindakan yang direncanakan, digerakkan dan dievaluasi secara teratur atas semua usaha demi mengakhiri konflik. Untuk kasus Fatimah ini ada beberapa cara untuk meminimalisir adanya konflik tersebut menurut Dhewanto (2012). Hal pertama adalah pencetus bisnis keluarga memberikan petunjuk dan membagikan secara terbuka dalam bisnis keluarganya, mulai dari visi dan misi, struktur organisasi yang ada dankegiatan bisnis dari bisnis tersebut. Kedua adalah dengan mengadakan rapat keluarga (family meeting) secara rutin. Family meeting ini merupakan cara terbaik untuk mempraktikan pemecahan masalah, meningkatkan komunikasi dan membangun kesatuan keluarga. Rapat keluarga yang dijadwalkan secara rutin ini memungkinkan untuk menghadapi keputusan sehari-hari seperti bagaimana suatu pekerjaan harus didistribusikan, sehingga dapat mengurangi terjadinya perselisihan atau konflik. Sayangnya, family meeting ini tidak dilakukan oleh keluarga besar Syahri. Sehingga setiap anggota keluarga jarang terlibat dan tidak terbiasa ikut campur dalam bisnis keluarga. Hal ini juga yang menyebabkan jiwa kewirausahaan tidak timbul di setiap anggota keluarga terutama anak-anaknya.

Dengan adanya pengalaman penolakan untuk melanjutkan bisnis keluarga dari anak pertama hingga anak ketiga. Syahri tetap tidak akan mempersiapkan anak keempat hingga anak keenam untuk melanjutkan bisnisnya. Beliau tetap beranggapan bahwa anak-anaknya memiliki citacita sendiri dan membiarkan anak- anaknya untuk memilih berkarir menjadi apa.

Setelah mendapatkan beberapa mata kuliah yang berkaitan dengan kewirausaahan seperti KWU (Kewirausahaan), PPB (Proyek Penciptaan Bisnis), PBS (Proyek Bisnis Sosial) di UISI (Universitas International Semen Indonesia). Fatimah merasa ada yang kurang setelah menempuh mata kuliah tersebut. Menurut Fatimah praktek langsung dari mahasiswa apabila mendengar kata "jualan" sering disalah artikan dan yang terjadi, mahasiswa lebih fokus untuk mencari laba semaksimal mungkin tanpa mematangkan konsep dari bisnisnya. Hal kedua, kontrol dari dosen pengampuh mata kuliah tersebut dirasa kurang. Dosen terkadang menggiring ide atau opini mahasiswa harus sesuai dengan ide yang dimiliki oleh dosen sehingga mahasiswa tidak bebas untuk menentukan bisnis apa yang dijalankan. Dari hal tersebut Fatimah memiliki beberapa saran yaitu, mahasiswa dibebaskan untuk menentukan bisnis apa yang akan dijalankan dengan syarat konsep wirausaha mulai dari modal sampai take action jelas. Mahasiswa UISI yang menempuh mata kuliah yang berkaitan dengan kewirausahaan lebih sering untuk ditugaskan untuk terjun ke beberapa usaha secara langsung untuk mengetahui seluk beluk bagaimana mendirikan suatu bisnis. Selain itu, sedini mungkin mahasiswa diberikan pembekalan mental tentang bagaimana menjadi seorang entrepreneur. Hal penting lainnya menurut Fatimah adalah mengingatkan agar dosen lebih sering membimbing dan mengontrol bisnis yang akan dijalankan oleh mahasiswanya secara langsung. 


\section{KESIMPULAN}

1. Generasi penerus tidak melanjutkan bisnis keluarga dengan alasan untuk menghindari konflik dengan keluarganya.

2. Bisnis keluarga yang dijalankan oleh Syahri ini hanya sekedar untuk memenuhi kebutuhan sehari-hari dan belum terpikirkan untuk mengembangkan bisnisnya.

3. Pencetus bisnis keluarga tidak pernah melibatkan anak-anaknya untuk langsung terlibat dalam usaha yang telah dirintisnya sehingga rasa kepemilikan tidak timbul dalam pribadi anak-anak dari Syahri.

4. Generasi penerus meninggalkan bisnis keluarga yang dimiliki keluarganya karena lebih memilih untuk berkarir di luar lingkup bisnis keluarga dan tidak tertarik sama sekali dengan dunia wirausaha. Selain itu, dia memiliki kepribadian yang tidak suka mengambil risiko dan suka cari aman.

5. Pencetus bisnis keluarga tidak melakukan proses suksesi terhadap bisnisnya karena beliau tidak memaksa untuk meneruskan usahanya karena calon penerus bisnis keluarga mempunyai citacita sendiri dan pencetus bisnis keluarga memutuskan untuk melakukan bisnisnya semampunya.

\section{SARAN}

1. Pencetus bisnis keluarga harus lebih terbuka terhadap setiap anggota keluarga tentang nilai-nilai yang ada di bisnis keluarga mulai dari visi dan misi, struktur organisasi dan kegiatan operasional bisnis tersebut.

2. Pencetus bisnis keluarga bisa merekrut tenaga profesional untuk membantu mengembangkan usaha miliknya. Sehingga usaha bisa tetap terus berjalan walaupun pemilik usaha jalan-jalan

3. Dalam bisnis keluarga milik Syahri sebaiknya membuat agenda untuk family meeting. Family meeting ini maksudnya adalah mengadakan pertemuan keluarga untuk berkomunikasi dan berdiskusi untuk membahas mengenai pengambilan keputusan, pemecahan masalah, dorongan dan kerjasama antar anggota keluarga. Dengan adanya agenda family meeting setiap anggota kekuarga dapat terlibat dan memberikan kontribusi dalam tersebut.

4. Dengan menanamkan entrepreneurship sejak dini dan dengan membiasakan generasi penerus untuk ikut terjun langsung dalam bisnis yang dijalankan oleh Syahri

5. Pencetus bisnis keluarga sebaiknya melakukan suksesi terhadap bisnis yang telah dirintisnya dengan memperhatikan 6 karaketristik dan perilaku seseorang yang pantas untuk mengambil peran sebagai pemimpin perusahaan menurut Carlock dan Ward (2001).

\section{DAFTAR PUSTAKA}

A.B, S., H.Wijanarko, P.Susanto, \& S.Mertosono. (2007). The Jakarta Consulting Group on Family Business. Jakarta: Division The Jakarta Consulting Group.

Awood, \& C.Gabour. (2007). Succession Planning Basics. United States of America: American Society for Training and Development.

Esteberg, K. G. (2002). Qualitative Methods in Social Research. New York: Mc Graw Hill. 
Hasibuan, M. (2013). Managemen Sumber Daya Manusia. Jakarta: PT Bumi Aksara.

Jajeli, R. (2016, November 18). UMK Jatim Tahun 2017 Digedok, Tertinggi Kota Surabaya. Retrieved November 24, 2017, from detiknews:https://news.detik.com/b erita-jawa-timur/d-3348975/umkjatim-tahun-2017-digedoktertinggi-kota-surabaya

Leach, P. (2007). Family Business The Essensials. Great Britain: Profile Books Ltd.

Liputan 6. (2016, Desember 13). Anak Tolak Warisan, Miliarder Ini Cari Pewaris Bisnis $R p \quad 1.221 \quad T$. Retrieved Maret 17, 2018, from Liputan6: http://bisnis.liputan6.com/read/267 6994/anak-tolak-warisan-miliarderini-cari-pewaris-bisnis-rp-1221-t

Martoyo, S. (2000). Manajemen Sumber Daya Manusia. Yogyakarta: BPFE.

Mathis, \& Jackson, R. L. (2002). Manajemen Sumber Daya Manusia. Jakarta: Edisi Pertama Salemba Empat.

Paradhita, E. A., \& Mukzam, M. D. (2017). ANALISIS PERENCANAAN SUKSESI KEPEMIMPINAN PADA PERUSAHAAN KELUARGA (Studi pada CV.Glompong Duta Boga) . Jurnal Administrasi Bisnis $(J A B) \mid$ Vol. 50 No. 2 September 2017, 49.

Rastogi, S., \& Agrawal, R. (2010, September 06). Intention of offspring to join the family enterprise: a study of Indian businesses.

Sayuti. (2004). Motivasi dan FaktorFaktor yang Mempengaruhi. Jakarta: Ghalia Indonesia.

Sedarmayanti. (2007). Sumber Daya Manusia dan Produktivitas Kerja. Bandung: Penerbit Mandar Maju.

Siregar, D. I. (2016, August 24). Sinergi Perusahaan Keluarga Bisa Tingkatkan Ekonomi Indonesia. Retrieved Desember 01, 2017, from METROTVNEWS.COM:

http://ekonomi.metrotvnews.com/m ikro/PNgOR64N-sinergiperusahaan-keluarga-bisatingkatkan-ekonomi-indonesia

Soedibyo, B. (2012). Business Responses to Future Competition. Jakarta: PT Gramedia Pustaka Utama .

Sudiro, A. (2011). Perencanaan Sumber Daya Manusia. Malang: Universitas Brawijaya Press (UB Press).

Sugiyono. (2012). Metode Penelitian Kuantitatif Kualitatif dan $R \& D$. Bandung: Alfabeta.

Wijaya, C. T. (2014). FAKTORFAKTOR MOTIVASIONAL YANG MENGKLASIFIKASI KETERLIBATAN MAHASISWA DALAM MENGAMBIL PERAN PADA BISNIS KELUARGANYA. AGORA Vol 2, No 2 (2014), 2.

Zubir, N. (2008). Membangun Bisnis Keluarga yang Solid dari Generasi ke Generasi. Jakarta: Hikmah (PT.Mizan Publika). 